\title{
Efficient and Effective Land Reservation Implementation for Good-Governance in LAS: A Case for Brunei Darussalam
}

\author{
Pengiran Harizan Bin Pengiran Haji Piut ${ }^{1 *}$, Khadijah Bte Husin², Robiah Bte Suratman ${ }^{3}$ \\ ${ }^{1,2,3}$ Department Of Real Estate, Faculty Of Geoinformation And Real Estate, Universiti Teknologi Malaysia, Johor, Malaysia \\ *Corresponding Author E-Mail: Awangkuharizan270@Gmail.Com
}

\begin{abstract}
The debate over governance is something that will not pass overtime or become outdated. Governance in its essence is significant to ensure proper and sustainable development. Efficiency and effectiveness in management on the other part is vital in ensuring goodgovernance continuity especially to those dependent on governance institutions. Land on the other hand is an important finite resource for development of a country that requires exclusive management and control. This in turn positioned Land Administration System [LAS] at a particularly critical situation, where one wrong turn would pose serious effect not just to the government, but the public at large as well. In a society where conservatism is an agenda for both its political and social institution, good-governance is highly a subjective issue. Brunei being as such nation has been experiencing challenges in the implementation of its LAS in the current years. Poised between being a full monarchical governance and the necessity of adapting to current liberal economies are striking to be a much sensitive issue to discuss. Thus this paper will alleviate the exploration of good-governance by measuring the extent of effectiveness and efficiency of LAS practices in order to achieve smooth delivery of land services towards good-governance and sustainable development. Since LAS is a vast subject, this study will only explore a particular land process delivery system, which is land reservation. The method used in conducting this study involves both qualitative and quantitative data collection method made through professional interviews and survey questionnaires. Questions are created specifically based on the 5 main indicators of goodgovernance practices. To validate the findings, a modified USAID-OCA tool framework is adopted by utilizing the 7 main criteria of organizational behavior assessment.
\end{abstract}

Keywords: Land Alienation; Land Reservation; Effective and Efficient; Good-Governance; Brunei Darussalam

\section{Introduction}

The issue on development has long been a crucial subject of discussion particularly with regards to national interests. Development is by far important as it determines the direction and status of a society as well as nations towards achieving their goals irrespective of their differences. Good-governance on the other hand are needed in the national, political, social and economic arenas where it should serve as a basis to guide and influence the convergence of globalization of the new millennium towards future development [1]. Both subjects are inter-related and complementary towards each other in achieving society's goal. But with the rapid increase of population and level of globalization around the globe, the challenges for development and governance are becoming more intense. These challenges has called upon a new perspectives for sustainable development and more strategic as well as comprehensive measures of sustainable development and goodgovernance in different areas, where ne of the areas is land administration.

Like any other nations in the world, Brunei has also experience rapid development and re-development. Coupled with its unique conservative monarchical political system and the needs for open policy towards global capitalist and liberal economies puts the country in pressure to cope with current social and economic design for sustainable development. Since her independence from British colonialism, land administration for national development in Brunei is seen as an important strategy considering the coun- try's limited source of economic revenue especially one that can be considered as sustainable. Thus positive steps have been taking place towards improving land administration systems through national development policies and planning for the country's social and economic developments. From feudal land tenure arrangements, the country has experienced much transformation in her LAS through the introduction of the Land Code and adaptation of the Torrens system by the British [2,3]. Fig. 1 illustrates such transitions.

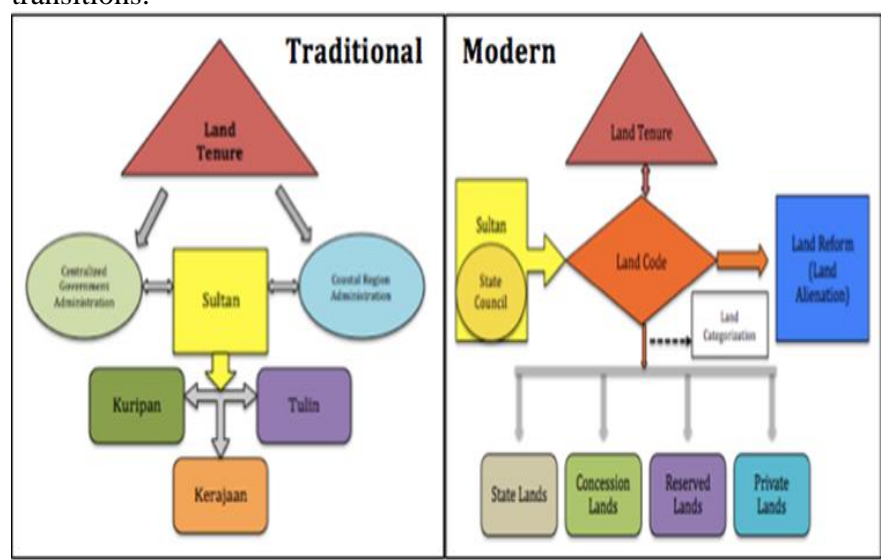

Fig. 1: Brunei's Feudal to Modern Land Tenure Arrangement. Source: Author's Own Study [2016] 


\section{Definition and Concepts}

Land studies are a vast field. Different perspectives perceive the study of land in different ways. From geography, politics, economics and social aspect of a nation, their attributes to land issues seem limitless. This paper focuses on the issues of land as an important commodity of a nation from which development can be generated from the latter. Land is one of the main resource by which life continues to carry on. As stated by Zuckerman [4], land is an essential feature of a nation's resources, hence the ownership and management of it are of the utmost importance. In other words, the existence of good land management and administration has much significance for the overall development of a country, particularly on the issues of land administration for sustainability as it represents the core aspect of land dealings. Thus came the highlight of good-governance in LAS.

\subsection{Good-Governance and Land Reservation}

To have good-governance is to have better government practice that promises effective, honest, equitable, transparent and accountable political, economic and social systems, which include regulatory of quality and rule of law as well as control of corruption. It also indicates that government is well managed, inclusive, and results in desirable outcomes [5]. Good-governance ensures that political, social and economic activities are determined by the voice of the society at large without elements of discrimination and social exclusions [6]. The big question is, can we really have such thing exist? Can something as close to as Utopia possibly be achieved? The term good itself is a very subjective topic. Different actors or organizations perceive good in different ways, so much as well the subjects that they govern. Different country or society favors different political and social arrangement. What 'good' perceived in a society might not be the same in the perspective of others. This is perhaps why it is very hard to constitute goodgovernance as a conceptual and practical practice, especially in a country that practices an absolute monarchical political system such as Brunei.

The need for broader perspectives on sustainable economies as well as social development and the necessity to maintain and protect its political system causes major challenges not just to governance, but the people at the same time. Good-governance turned out to be a very sensitive issue considering the country does not allow freedom of speech with relation to political administration. From the government's point of view, the country knows what's best for the people and that the society adhere and should be content with the monarch's just and welfare ruling. From this point on, the question on good-governance does no longer purely applied. Thus for one to understand how good governance are carried out within the country, a 'sugar-coated' approach must be undertaken. Land reservation in the context of Brunei Darussalam is part of land alienation process. In general sense, land alienation is defined through law as the transfer of property and possession of lands, tenements, or other things, from one person to another [OED, 2010]. Conceptually, alienation of land is as described by Marx refer to fundamentally related to property and the society with particular reference to labor capital with or without property possessions [Cox, 1998]. Its complex phenomenon can only be understood through manifestations of societal history where such alienation occurs. However, to describe the term land alienation in Brunei is epistemologically difficult as there is currently no exact definition made for it. This is also the case with reservation of land. What referred to as land reservation is as provided by the country's Land Code [LC] provisioned under Cap.40 Sec.3. According to the LC, what constitutes land reservation in the country are basically categorization and processes as well as procedures implementation. In some countries, definition of land processes or systems are made in accordance to the general meaning of the term itself. For instance in Malaysia and Singapore, land alienation referred to as the government giving land [as means of land disposal]. In the case of Brunei, such definition was never formal- ly made or prioritized. Land reservation is significant in the development of the country. Generally, reservation is defined as:

- An arrangement to have something held for use at a later time.

- The act of keeping back, withholding, or setting apart.

- A tract of public land set apart for a special purpose [7]

If we relate this to the working concept of land reservation, it can be concluded that the term is meant to describe the processes involved in parting or making exceptions on particular land lots for the use of specific government agencies mainly for public and developmental purposes. In Brunei, the LC identifies the authority of His Majesty's government to reserve state land for the purpose of public interests. These purposes include reservations made for: public utilities and infrastructures development; administrative, social and religious buildings; and economic development capacities.

Looking at the importance and potential of this LAS, it is prudent to approach it in a comprehensive manner as to understand better the system itself and to make it more viable and acceptable to every level of society. But this would require attention to goodgovernance in administration, which in the sense of Brunei is a very sensitive subject. This is why the researcher has chosen a much softer attitude in understanding the current land administration practice of the country that is to put into test the effectiveness and efficiencies of land alienation processes and procedures. Efficiencies and effectiveness are two important attributes of good land administration governance especially with relation to governing bodies and institutional capacities [4, 6, 8-10]. In fact, both characteristics can be regarded as main pillars that determine the direction of other good-governance attributes whether the latter are successful or otherwise. Fig. 2 illustrates this conceptual approach.

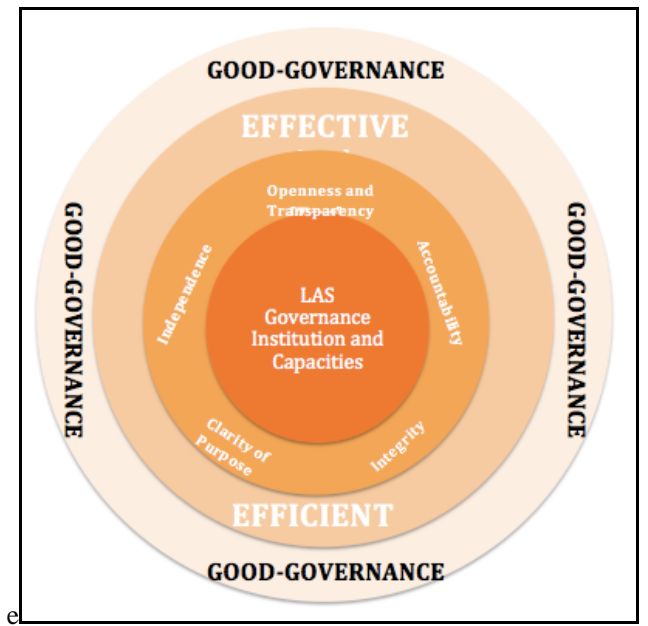

Fig. 2: Relationship Model for Effective and Efficient LAS Source: Author's Own Study [2016

\subsection{Background and Structure}

Land Reservation in Brunei can be traced as far back as the 1907 with the introduction of the LC. Before the establishment of a separate departmental section responsible in administering land alienation, reservation of land is under the authority of the Resident's Office. The changes brought upon by promulgation of the Brunei's Constitution 1959 opens up new demography for land administration, where reservation of land was put under the administrative functionality of the Commissioner of Land. When Brunei approaches its full independence in the year 1984, the responsibility fell under a section known as the Project Section. Finally in 2002, the Land Management and Alienation Section were formally established. Currently, the section's workforce is made up of 26 working staffs in total, each with different responsibilities and tasks. 


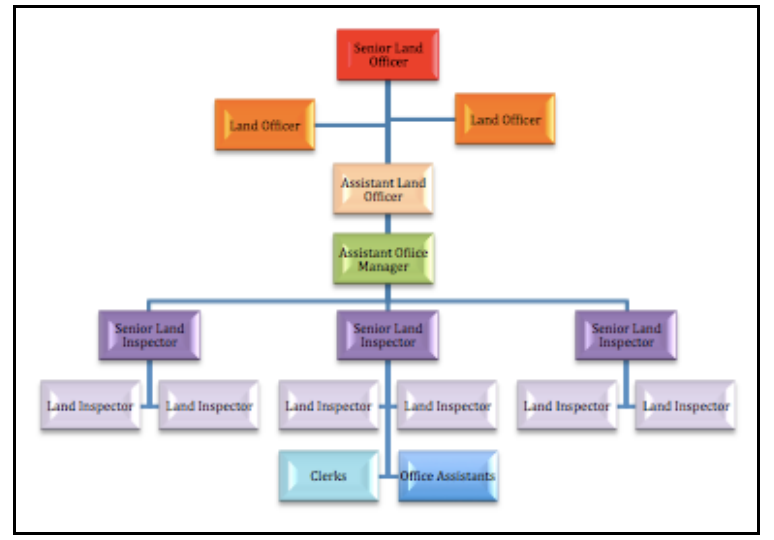

Fig. 3: Land Management and Alienation Section Organizational Structure Source: Author's Own Study [2016]

As shown in Fig. 3 above, the unit is lead by a Senior Land Officer aided by 2 Land Officers as the main blocks of authority or decision makers. They are aided by support staffs that include Assistant Land Officers, Assistant Office Manager, Senior Land Inspectors, Land Inspectors, Clerks and Office Assistant.

\subsection{Current Practices}

As described from previous definitions, reservation of lands can only be provided to government agencies. However, it is also possible for such reservations to be converted into land lease, rented property or even private lands [see Fig. 4]. These conditions are subjected to stipulations provided by relevant agencies given responsibilities to their respective reserved land of course the LC itself. Hence, it is possible to state that the role of land reservation is important in determining the direction of land alienation.

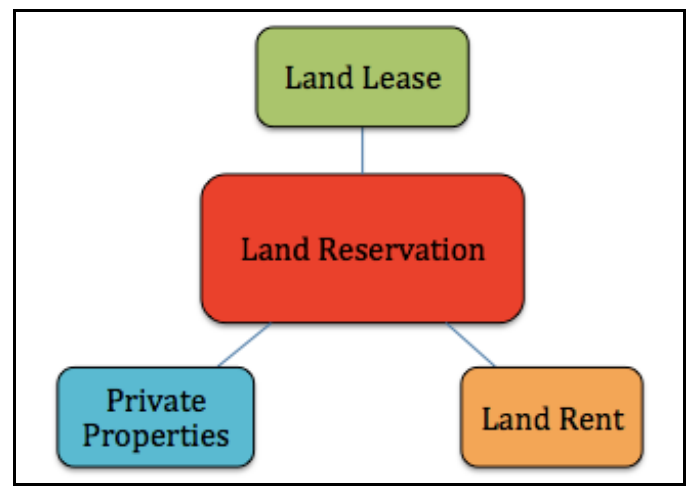

Fig. 4: Land Reservation Outcomes

Source: Author's Own Study [2016]

\subsection{Reservations into Land Lease}

Land reserved to government agencies may be leased or subleased as long as the policy and procedures does not contradict the $\mathrm{LC}$ as provisioned under section 4. Sub-leasing of this type is prioritized for industrial project that involves economic development especially one to attract foreign direct investments [FDI] and Domestic Investment Participation [DIP]. Currently, sub-leases are given to semi-government agencies and companies mandated to managing government development projects such as the Sungai Liang Industrial Park [SPARK] and the Pulau Muara Besar Industrial Project [PMB].

\subsection{Reservations into Land Rent}

The position of Land Officer is equal to Land Administrator in Malaysia.

Besides stipulation given by the code, the possibilities of renting reserved land are subject to respective agencies roles and responsibilities in promoting economic development through Small and
Medium Enterprises [SME] as well as agricultural activities. Among such activities includes; open space or land for commercial events; industrial and manufacturing sites; and tourism attractions.

\subsection{Reservation into Private Lands}

The conversion of reserved land into private property is conceivable under the RKN, STKRJ and Land Grant for Government Officers scheme. The main driving force under this category is the JKP as the responsible agency in strategic planning and implementation of housing developments and land distribution. Through this method, land is given entitlement to individuals who met the criteria underlined by respective agencies.

\subsection{Types of Land Reservation}

Reservation of lands is permissible to the government for the purpose of public utilities and infrastructures developments [such as roads, drainage, water pipes etc] as well as government buildings and other land requirements. Under this method, any government agencies that require lands for specific purposes may apply for reservation of land as provisioned in the Land Code CAP $40 \mathrm{Sec}$. 9 and 31 [v]. Consistent to this provision stipulated above, the government under its authority may not alienate any reserved land for purposes other than what it was originally intended to, and that the agency responsible for such reservations are deemed in charge of its development. Governed by authority given to respective agencies and subsequent to finalization of reservation [gazette], they are permitted to either sub-lease or rent their reserved land for purposes deemed recognized and acceptable by policy undertaken from time to time. Reservation of land may also involve private, lease or TOL land. The acquisition of these particular lands will be subjected to provisions under the LC section 9 and the Land Acquisition Act CAP.41. Sec.3. Currently there are two types of government reservation [see Fig. 5], which are the Linear Reserves and the Site Reserves. Linear reservation of land refers to the alienation of land for construction of public utilities and infrastructures that are linear in nature such as roads, drainage, pipelines, electric cables, bridges and so on. On the other hand, site reservation refers to alienation of lands for government projects that requires a particular site such as for office buildings, mosques, schools, graveyards, stations, residential sites, commercial or industrial areas and etc.

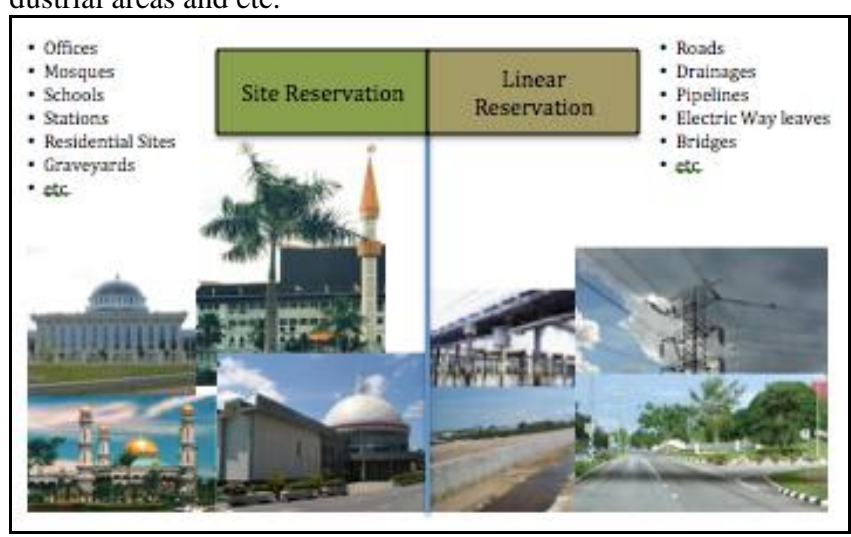

Fig. 5: Types of Land Reservation Source: Author's Own Study [2016

Unlike other modes of alienation, land reservation requires collaboration from other interested government and non-government agencies especially during the stages of site selection or if such reservation involves any acquisition of lands. But the main cooperative agencies that plays important role alongside land department includes Town and Country Planning Department [TCP], Survey Department [JUA], Public Works Department [JKR], District Offices, Housing Development Department [JKP] and Department of Environment, Parks, and Recreation [JASTRE]. These 
agencies are vital especially in terms of policies and decision identification as well as their undertakings.

\section{Methodology}

This paper is aimed at measuring the current effectiveness and efficiency of land reservation processes and procedures implementation towards achieving good-governance of LAS in Brunei. In doing this, several techniques are adopted in order to reach a sensible and validated conclusion. Data were derived from both qualitative and quantitative method through literature reviews, professional interviews and survey questionnaires respectively. Since the main objective of this research is to measure the level of effectiveness and efficiency of land reservation processes and procedures implementation, two modified research tools will be adopted; the USAID-Organizational Capacity Assessment Tool [11] and Good-Governance Principles as measurement indicators [Fig. 7]. These methods will be conducted in stages as illustrated in Fig 6.

\begin{tabular}{c|c|}
\hline Literature Reviews \\
\hline Interviews \\
Survey
\end{tabular}

\section{Good-Governance Principles}

PERFORMANCE ANALYSIS (USAID-Organizational Capacity Assessment Tool [OCAT])

Fig. 6: Methodological Approach Stages

Source: Author's Own study [2016]

Referring to the above, the first stage are mainly on literature reviews, which are important in understanding the concept and importance of land reservation in the context of the country of study. This followed by the professional interviews method that provides the opportunity for thorough investigation on current land alienation policy practices. For this, 10 principle informants were selected through expertise-sampling strategy, where samples are selected based on their professionalism and experienced involvement with regards to land reservation, where analysis of data collected is made using simple descriptive analysis. On the other part, survey questionnaires were made to quantify organizational behaviors, participations and opinions with main purpose to gather information from government employees or interested party on questions related to the objectives of this study. Since it is hard to determine the exact total population to refer to, samples are chosen using purposive and snowball sampling techniques to attain population relevance in the subject area. In total, 276 questionnaires were distributed [see table 1]. Questions are designed based on the 5 indicators of efficient and effective land administration criteria as illustrated in Fig. 7. The choice of such classifications is based on three main criteria:

Such principles are mutual among most literatures assessed;

1. They can be easily associated within the scope of land governance;

2. Though many principles indicated in many of the literatures, but most of them overlapped, as such, principles chosen in this study are summaries of them all.

\begin{tabular}{|c|c|c|c|c|}
\hline $\begin{array}{l}\text { NO } \\
.\end{array}$ & $\begin{array}{l}\text { DATA COL- } \\
\text { LECTION } \\
\text { TECH- } \\
\text { NIQUES } \\
\end{array}$ & $\begin{array}{l}\text { SAMPLING } \\
\text { TECH- } \\
\text { NIQUE }\end{array}$ & $\begin{array}{l}\text { SPECIFIC } \\
\text { TECH- } \\
\text { NIQUE }\end{array}$ & $\begin{array}{l}\text { VARIA- } \\
\text { BLES }\end{array}$ \\
\hline 1 & Interviews & $\begin{array}{l}\text { Non- } \\
\text { Probability }\end{array}$ & $\begin{array}{l}\text { Purposive } \\
\text { Sampling }\end{array}$ & 10 \\
\hline 3 & Questionnaire & Probability & $\begin{array}{l}\text { Purposive } \\
\text { and Snowball }\end{array}$ & 276 \\
\hline
\end{tabular}

Source: Author's Own Study [2016]

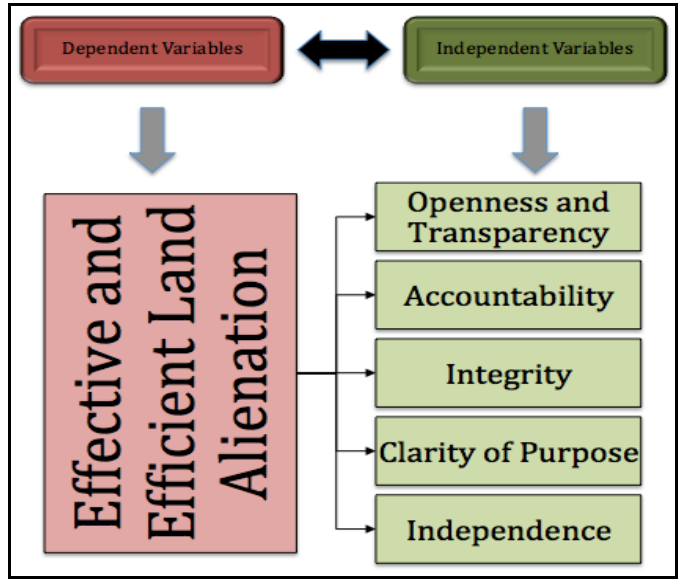

Fig. 7: Effective and Efficient LAS Indicators

Finally, performance measurement will take place. For this stage, modified USAID-OCA Tool will be adopted. The OCAT is a ramework tool used by the United States Agency for International Development [USAID] with the main aim to improve efficiency and effectiveness of an organization by: determining where it stands on a variety of its components; identifying an organization's relative strengths and weaknesses; as well as recognizing priority areas of improvement. It is a holistic and self-assessment approach towards identifying capacity and capabilities [11]. By applying this technique, data collected from the previous stages are integrated and assessed using the 7 indicators framework of the tool [Fig. 8]. Each indicator is designated with relevant enquiry significant to identifying the land reservation's processes and procedures performance as listed.

- Governance [Organizational Structure, mission/goal, leadership, legal status],

- Management Practices [Information management and administration procedures],

- Human Resources [Human resources development],

- Financial Resources [Financial Records and Filing],

- Service Delivery [Impact assessment],

- External Relations [Internal and External Communications],

- Sustainability [Management Changes and Succession].

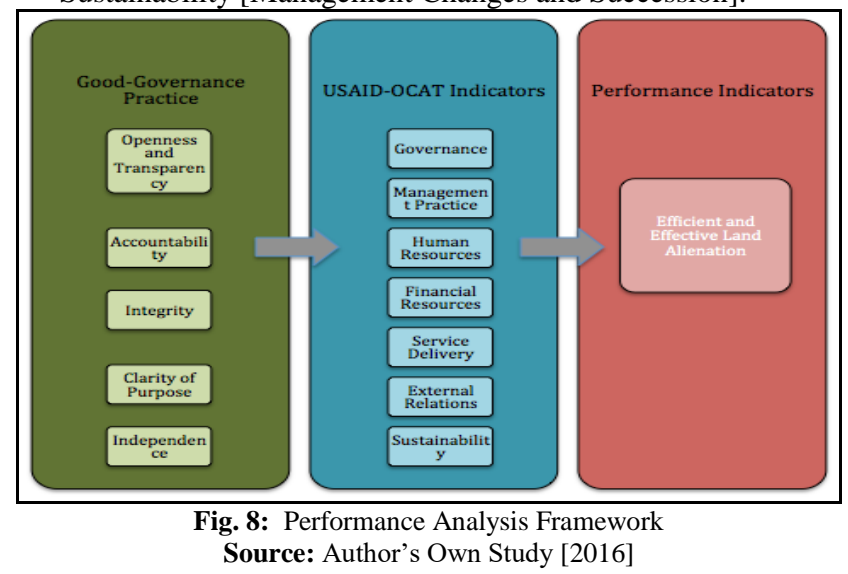

These enquiries will be measured using scale bearings similar to the likert scale as stated in table 2. In order to avoid bias conclusions, measurements are made by applying the MDM method where selected interviewees are the mediator in giving classification scales.

\subsection{Performance Evaluation}

\subsection{Current Practices}

Land reservation is under the responsibility of the Land Alienation and Management Section. Signified earlier, land reservation pro- 
cesses can be divided into linear reservation and site reservation. In the context of procedures and processes, the only difference between the two is the initial stages of site selection. Commonly, linear reservation will go straight to Land Management and Alienation Section for assessment of project alignment. The assessment includes: identification of and types of land involved in the projects [private land, reserved land, TOL's, leased land and so on] should there be a need for acquisition; project alignment viability for commencement; expenditure control; and map/plan finalization. After internal assessment completed, the project map/plan will be circulated to interested government agencies for comments and reviews. Should there be any encumbrances on the said map/plan, it will be reviewed again by its respective applying agency for realignment.

On a dissimilar note, site reservation will first go through filtering process by the TCP department. This is to ensure that any site selection under this category is in line with the country's NLUMP as well the department's role as planner for land-use and development in the country. The TCP is also the chairing department for the Diminutive Site Selection Committee [Jawatankuasa Kecil Pemilihan Tapak] whose authority given by the Ministry of Development in the initial approval of any selected site for government projects before being forwarded to further assessment by higher authorities. This committee convenes once a month to endorse any site application from each member. Approved application will be handed down to Land Department for reservation processes. After project map/site has been approved, Land Department will proceed with reservation preparation and this includes:

Table 2: Modified USAID-OCAT Classification Scales

\begin{tabular}{|l|l|l|}
\hline $\begin{array}{l}\text { Confidence } \\
\text { Level }\end{array}$ & Capacities & Unique Traits \\
\hline 1 & $\begin{array}{l}\text { Low Ca- } \\
\text { pacity }\end{array}$ & $\begin{array}{l}\text { Usually referred to as the lowest or least } \\
\text { trait. It is typically uttered in negative con- } \\
\text { notations such as inexistence, unavailable, } \\
\text { unclear, or undocumented. }\end{array}$ \\
\hline 2 & $\begin{array}{l}\text { Basic } \\
\text { Capacity } \\
\text { quate and weak characteristics. Although } \\
\text { sometimes it is characterized in the least } \\
\text { possible manners, incompleteness surrounds } \\
\text { this trait. }\end{array}$ \\
\hline 3 & $\begin{array}{l}\text { Moderate } \\
\text { Capacity } \\
\text { trays the ability to show positive character- } \\
\text { istics such as adequacy, proper and availa- } \\
\text { bility. But somehow there are still more or } \\
\text { some room for improvements. }\end{array}$ \\
\hline 4 & $\begin{array}{l}\text { Strong } \\
\text { Capacity }\end{array}$ & $\begin{array}{l}\text { Strong capacity demonstrates contentment } \\
\text { and fulfillment. It usually presents complete } \\
\text { and comprehensive coverage of needs and } \\
\text { requirements. }\end{array}$ \\
\hline
\end{tabular}

Source: Author's Own Study based on the USAID-OCAT [12]

- Site/alignment inspection and full report,

- Finalization of project map/alignment,

- Valuation of private land, TOL's, and leased lands [if required],

- Acquiring consent letter from owning agencies of gazette land [if required],

- Completed Reservation Application Form from applicant,

- Preparation and finalization of council paper.

Once everything is completed, the council paper will then be forwarded to the Ministry of Development, who then through its Housing and Land-Use Division will pass it to the Prime Minister's Office for submission to His Majesty in Council's approval. Following receiving consent from authorities stated above, the department would then carry on with the process of gazette [through the Attorney General Chambers], application for gazette map/plan to the Survey Department, and producing Reservation Certificate for the owning agency. Whilst receiving information regarding the approval of reservation, the applying agency may proceed with their intended development.
Besides the normal procedures of enabling development processes above, project implementer agencies may apply for early entry for survey and demarcation purposes as well as development providing that there are no private properties or other government gazette involved. If such properties were to be included in the application, application Declaration needs to be made, and that only survey may be done. Appendix 1 simplifies these working procedures so that it could be easily comprehended. The table includes processing duration of each procedures as well as the level of staff handling each of them respectively. Appendix II and III illustrates and indicates the differences between linear reservation and site reservation procedures.

\section{Contribution}

For over a century, land reservation has offered significant contribution in the development of the country. Although appeared micro in scale, one needs to consider the fact that the role of reservation of land in development is extensive and that its input are much greater in providing for public services, infrastructures as well as governance arrangements. In summary, the contribution of land reservation can be divided into national, social and economic [see Fig. 9].

It is impossible to acquire in time a comprehensive statistics that refers to the total amount of land reserved in the county, as the data were either unavailable or scattered across personal files. According to compiled report from projects personal files, as of 2016, the section has been processing a little more to 4,000 applications for land reservation from different government agencies as well as quasi-governmental agencies. These reservation ranges from linear type of reservations [such as roads, drainages, way leaves] and site reservations [such as government buildings and public utilities]. Appendix IV summarizes the compilation according to respective department agencies.

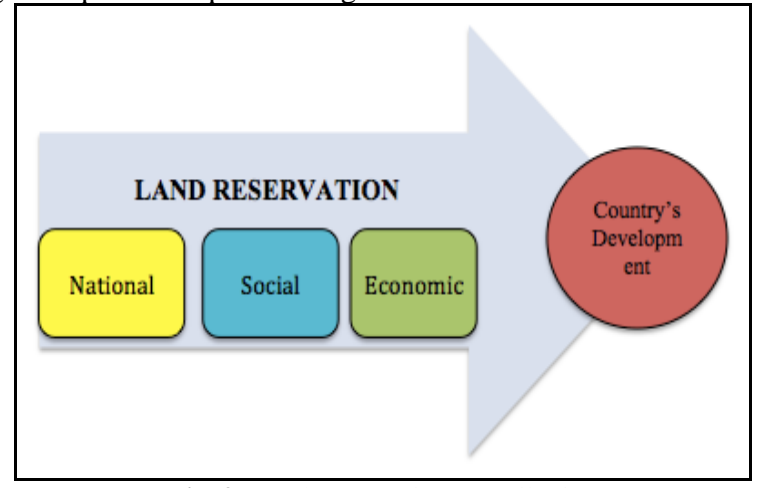

Fig. 9: Land Reservation Contribution Source: Author's Own Study [2016]

\subsection{Issues and Challenges}

The results obtained from observations and interviews reveal quite a number of issues and problems faced in the implementation of land reservation. These challenges can be divided into institutional, individuals and processes. Fig. 10 presented these divisions.

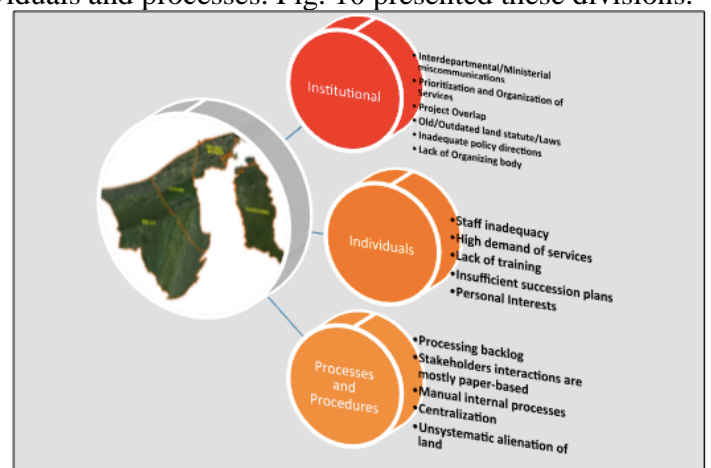

Fig. 10: Issues and Problems in the Implementation of Land Reservation Source: Author's Own Study from Interviews and Observations [2016] 
Institutional challenges refer to issues and problems that emerge from institutional background, specifically the Land Management and Alienation section and its counterparts in handling land reservation. Lack of coordination, time-consuming communication, project overlap among agencies, outdated statutes, inadequate policy directives as well as lack of organizing bodies are all issues currently challenging smooth deliveries of services. Besides institutional challenges, individuals also pose several issues and problems in implementing land reservation. Individuals refer to those who are directly related to land reservation processes and procedures. The problems associated with this includes staff inadequacy, high service demand, lack of training for staffs, insufficient succession plans as well as personal interests. Lastly are the issues and problems related to process and procedures in implementing reservation of land. Such problems include process backlog, communication problems with stakeholders, manual internal processes, as well as the issue on centralization vs. decentralization of data.

\section{Survey Findings}

Fig. 10 below shows the summary of findings compiled from survey questionnaires. From the chart summary, it is clear that most of the responses acquired from the survey indicated high level of disagreement among the respondents with regards to availability of the 5 main indicators of efficient and effective land administration. In other words, the data implies shortcomings of required criteria if we are to consider employment of good service deliveries to stakeholders, particularly in land reservation application. But to have this statistics alone would not be enough to reach solid conclusions. Thus system measurements will be made further by applying the USAID-OCA tool as explained before this.

\subsection{Performance Analysis}

As stated earlier, performance analysis is made using the modified USAID-OCAT framework by utilizing the 7 main value criteria of organizational governance that are crosschecked with all the data acquired. The results are as shown in Fig. 11

In terms of organizational structure, the inadequacy of staffs and unavailability of policy directives has been a major problem in day-to-day running of the section's activities. Although in the context of organizational structure that the section is adequate and systematic, some major updating are required especially on critical areas. For example, the section should have more personnel responsible in the production of council papers, as this will significantly improve the speed of application delivery to respective agencies. Another problem that is associated with organizational structure is failure to adhere with current hierarchical standard of procedures among office holders. This is also due to shortcomings provided by lack of directives as well as knowledge information. In the end, respective office holders would look for alternatives in finding solutions to their problem, thus resulted in unorganized hierarchical behaviors. Alongside this, line of authority becomes unclear and problematic. There are cases where miscommunication between officers and higher authorities with regards to decision-making put pressures and confusion among lower level staffs. Mission and vision are two among the most critical element in an organization. Just like structural composition and staff orientation, it will determine the integrity and direction of the organization itself. Thus it is severely important that all individual at every level of the management aware, understand and appreciate their respective organization's vision and mission. Although it would be a rather bold statement to say that there are some of them who could not care less on the subject matter, but as some of the respondents interviewed stated, it is an actual fact. Besides this, the issue on relevancy of current mission and vision are also questionable especially in today's advancement of social and political agenda.
On leadership matters, overlapping of directives as well uncertainties among staff with regards to such directives created rifts in the smooth running of processes and procedures. And this problem would become much worse should outside elements interfere with internal authorities.

The next assessment is on legal statutes. The point of having legal status is to have legitimacy over authorities and activities. As discussed in-depth before this, the Land Code provided the government for a firm stand on its authority over land matters in the country. But the lack of specific provisions and updates on the code itself are hindering the smooth transitions and implementation of authorities among respective office holders. As a result of this, confusion and authoritative rift are created in delivering service quality. There are in several cases that the status of Land Department as land administrator in the country is step over by other agencies in terms of decision-making and planning. Furthermore to this, the position of land administrator as land champion is most of time overshadowed.

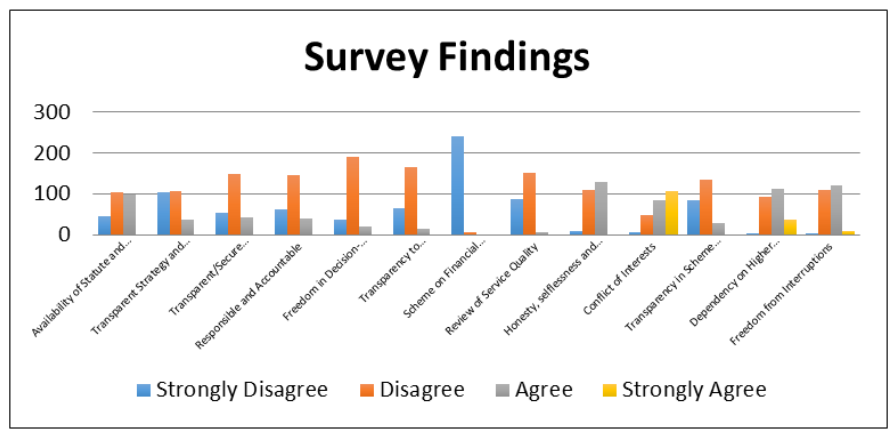

Fig. 11: Questionnaires Survey Findings

Source: Author's Own Study from Field Survey [2016]

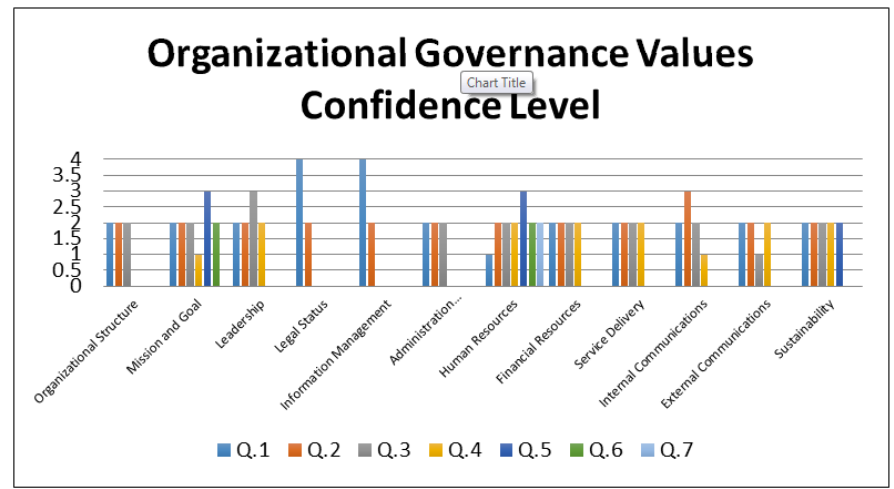

Fig. 12: Organizational Governance Values Confidence Level Source: Author's Own Study from Field Survey [2016]

On the other note, the significance of information seeks beyond a specific organization's interest, where the contribution that could be made reaches out to stakeholders and other parties concerned. In land reservation businesses, information is crucial in saving cost and time. Analysis of data acquired proves that this is one aspect that the Land Management and Alienation section is lacking. Although there are efforts to disseminate information with regards to land reservation processes and procedures, it is evidenced that they are inadequate and sometimes inaccurate. This is partly due to interventions and uncertainty in implementation, which in the end causes breaks in standard of procedures.

Following from this is the problem of transparency. Unavailability of certain information with regards to application status has always been a major concern for stakeholders. This is especially when such application are not in the hands of the Land Department anymore. Since the section is the middle agency for application, stakeholders would seek the department for conformation. When they could not get the answers they are looking for, land department would be blame for incompetence.

As common as it may sound, administrative procedures are recurring issues faced by any organization. Although at some point some managed to overcome major associated problems, somehow 
new challenges keep on coming. The Land Management and Alienation section comprises of a systematic administrative structure and procedures. But confronted with overwhelming task as well as unclear policy directions are causing the section's programs not to behave accordingly. To add into this, personal problems and obligations among employees are making things worst. Work delays and improper channeling of task are posing serious impediment to work processes.

Another issue that needs to be highlighted is the method by which procedures are managed. As evidenced through the surveys, administrative practices in the section are mostly managed manually, using filing and documentation system for application proceedings and records. Full utilization of ICT is yet to be realized, which can significantly improve processes and procedures implementation. Related to organizational structure, human resource capacity and development are significantly required to achieve maximum potential of any organization. The main purpose of human resources development is to acquire, train and produce competent as well reliable office holders at every level of management capacities. According to some of the informants, the current method by which employees are hired for the department is still inconsistent and unsystematic. Although there are field requirements consistent with job description, selection of employees is mostly based on their performance during written tests and interviews. Furthermore, such field requirements and job description are often too general. Thus it resulted in rooms for job mismatched and in the end putting more negative pressure on the organization itself. Another issue brought into attention during the interviews is the problem of staff training. As explained in detail, job requirement in land reservation requires specialties and trainings in order for familiarization. Current provisions for training are either unavailable or incomplete. Thus knowledge on processes and procedures are left without proper continuity and succession plans.

Other than technical capacities, financial statement delivery is also crucial in the process of land reservation appraisal especially when such project involved private lands acquisition, such as project budget requirements, compensation values and so on This is the main reason why the section is currently working closely with the Valuation section of the Land Department. The main problem associated with this is mainly on communication issues with regards to valuation and calculation of any such compensation. Understaffs as well as human errors [miscalculation, valuation overlap, documentation misplacement] might sounds a bit exaggerated, but the fact it poses serious problems are real. Furthermore, the manners in which records are kept [manual documentation and filing] are still inefficient and inconvenient especially when referrals are needed from stakeholders.

Indicated as one of the main goal of an organization, service delivery is another important elements that should be measured. Service providing in nature, the ability of the section in giving prompt and excellent job delivery are crucial elements towards the sustainability of the organization itself. Impact assessment is one essential feature that needs to be addressed. The problem with delivery of service within the Land Management and Alienation section is the failure to provide prompt and on time completion of an application. As proven in previous discussion, it would sometimes take more time than it should to have an application appraised. Although the blame should not be put solely on the department, perhaps more can be done internally. So far there has been no comprehensive impact assessment programs conducted to examine the current situation.

More along the line of service deliveries, external relations are equally important. The performance of an organization is critically evaluated by outside elements, especially ones that the former are providing services for. Good internal communication within the department is crucial, as it will assist in promoting efficient and effective service delivery. Rapport among staff members and office holders are also an important feature in providing better cooperation and workmanships. In the case of the Land Management and Alienation section, this is proven to be difficult. Personal vendettas, individuality, and miscommunications are among the criti- cal problems faced. The same thing goes with external relations. To add to this, current networking and collaboration with relevant agencies in reserving lands are proven to be difficult.

Finally, sustainability that mostly refers to the ability of the section in adapting to changes in management as well as the issue on succession is equally important. As explained earlier, the lack of knowledge transfers and unavailability of relevant information has caused succession planning to be difficult. As a result, adaptation to work processes and procedures among new office holders becomes timely and complicated.

\subsection{Final Assessment}

The major finding of the study reveals that the processes and procedures implementation of land reservation is mostly ineffective and inefficient. As shown in Fig. 12 above, the confidence levels of each governance indicators critical in observing the Land Management and Alienation section's performance are mostly below average and indicated basic capacity. These are mostly resulted from the problem of lacking in statutory and legal provisions, unclear strategy or process implementation, irresponsible and unaccountable office holders as well as insecure succession of knowledge and experiences. Such ineffectiveness and inefficiencies has resulted in quite a number of challenges, which in turn poses detrimental effect, not just to land administration, but towards proper and progressive development. Just as proven from the discussions above, the problem associated with such ineffectiveness and inefficiencies also affected other parties or stakeholders. Whether directly or indirectly, issues and problems that it imposed extended towards institutional, operational as well as outcome of these organizations. Since land alienation is part of the bigger picture of land governance in the country, one need to wonder how far does good-governance in land administration and management are taken into consideration for sustainable development.

\section{Conclusion and recommendations}

As the study indicated, much of the good-governance principles chosen to indicate effective and efficient practice are weakly implemented and practiced whether in terms of organizational capacities, statutory bodies as well as policy directions. The lack and unavailability of policy directives as well as statute [land code] proves to be one of the major causes for work delays and uncertainty in handling tasks and responsibilities among office holders. Unclear, unreliable and scattered information on processes and procedures are becoming worrying trends for stakeholders to trust relevant agencies in conducting their respective practices. As a result of this, these stakeholders tend to approach unreliable sources of information and authorities for actions. Thus, this has created mixed and unclear jurisdictions and authorities in governance. Besides this, the issues on office holder's accountability are also of major concerns. To choose between work responsibility and personal obligations seems to be harder than it may sound. This does not include work burden that these office holder's need to face every working days. Rationally, motivations for work are becoming harder to attain. Thus, a perceivable solution needs to be addressed. It does not matter if such solutions should start small or otherwise, something needs to be done for the benefit of the society and the country at large. It is recommended that more focus studies should to be made in order to achieve systematic and overall solutions to the problems at hand. This is due to the potential of land reservation as catalyst for development and sustainability.

\section{Acknowledgement}

The authors are grateful to Land Administration and Development Studies [LAnDS] members for the assistance in completing the paper. 


\section{References}

[1] Osman S, Awang Z, Naidu S. Good Governance: Issues and Challenges. Kuala Lumpur: National Institute of Public Administration [INTAN]; 2001. 286 p.

[2] Hassan PAWbP. Land Reform in Brunei Darussalam: Towards Sustainable Resource Management. [Master's Thesis]: University of East London; 1997.

[3] Mail DHAAH. Kesultanan Brunei KM XIX, Sungai Kerajaan, Sungai Kuripan dan Sungai Tulin, Hubungannya dengan Pentadbiran Rantau Pesisir. Jurnal Darussalam. 2006;6.

[4] Zuckerman SZ. Land ownership and resources; a course of lectures given at Cambridge in June 1958. Cambridge: Dept. of Estate Management; 1960. 136 p. p.

[5] Grover R, FAO. Good governance in land tenure and administration. Rome: Food and Agriculture Organization of the United Nations; 2007. 57 p. p.

[6] UNDP. Governance for Sustainable Human Development. Washington DC: UNDP; 1998.

[7] Stevenson A. Oxford dictionary of English. New York, NY: Oxford University Press; 2010. Available from: https://gate2.library.lse.ac.uk/login?url=http://www.oxfordreference .com/view/10.1093/acref/9780199571123.001.0001/acref9780199571123

[8] Good Governance in Land Administration [Internet]. FIG. 2007 [cited December 22nd, 2015]. Available from: https://www.fig.net/resources/proceedings/fig_proceedings/fig2007 /papers/ps_03/ps03_01_bell_2219.pdf.

[9] Good-Governance in Land Administration: Principles and Good Practices [Internet]. Food and Agriculture Organization of The United Nations [FAO]. 2009 [cited December 15th, 2015]. Available from: http://www.fao.org/docrep/011/i0830e/i0830e00.htm.

[10] Williamson IP. Land administration for sustainable development. 1st ed. Redlands, Calif. LaVergne, TN: ESRI Press Academic ; Distributed to the trade in North America by Ingram Publisher Services; 2010. xv, 487 p. p

[11] United States Agency For International DevelopmentOrganizational Capacity Assessment for Community-Based Organizations. [Internet]. John Snow Inc. 2012 [cited February
12th, Available from: https://www.usaid.gov/sites/default/files/documents/1864/OCA\%20 Too1\%20for\%20Community\%20Based\%20Organizations.pdf.

[12] Organizational Capacity Assessment [OCA] Facilitator's Guide Version with NUPAS Items [Internet]. 2014 [cited February 20th, 2017]. Available from: https://usaidlearninglab.org/sites/default/files/resource/files/ocawith facilitatorsguidewithnupas7.10.2015.pdf.

\section{Interviews}

Awang Haji Yunaidi bin Haji Yunus [2016, Dec 16]. Head of Brunei/Muara District Land Office/Senior Land Officer, Personal Interview. [Respondent 1]

Dk Hjh Salbiana bte Pg Haji Ali [2016, Spetember 10], Senior Officer, Minister of Development, Personal Interview [Respondent 2].

Awang Hamdani bin Haji Masri [2016, Dec 14]. Head of Land Management and Alienation section/Senior Land Officer, Personal Interview [Respondent 3].

Awang Haji Mohd Gazalin bin Pengarah Haji Mokti [2016, Dec 18]. Acting Assistant Commissioner of Land, Personal Interview.

Dayang Mardianah bte Mohd. Zaini [2015, Sept 15]. Project Mapper, DDS, Personal Interview [Respondent 4].

Awang Musa bin Haji Sulaiman [2016, Dec 14]. Land Officer, Personal Interview [Respondent 5].

Awang Haji Lihan bin Haji Ibrahim [2016, Dec 21]. Town and Country Planning Officer, Personal Interview [Respondent 6].

Awang Haji Syukor bin Haji Kassim [2016, Dec 21], Housing Officer, Personal Interview [Respondent 7].

Awang Rushdi bin Mohammad Tahir [2016, Dec 15]. Land Inspector, Personal Interview [Respondent 8].

Dato Paduka Awang Eddie bin Dato Paduka Awang Haji Sunny [2014, October Permanent Secretary [Technical and Professional], Ministry of Development, Personal Interview [Respondent 9].

Datin Hajah Zainon bte Abang Haji Omarzuki [2016, Dec 18]. Land Commissioner, Personal Interview [Respondent 10]. 